\title{
An experimental study of the water and heat balance in the source area of the Ürümqi River in the Tien Shan mountains
}

\author{
Kang Ersi, Yang DaQing, Zhang Yinsheng, Yang Xinyuan \\ AND SHI YAFENG \\ Lanzhou Institute of Glaciology and Geocryology, Academia Sinica, Lanzhou 730000, China
}

\begin{abstract}
In the source area of the Ürümqi River, during the glacier ablation season, net radiation is the only heat input to the tundra, averaging $119 \mathrm{~W} \mathrm{~m}^{-2}$ in July and August, more than twice that to the glacier, where additional heat input is contributed by sensible heat. The heat input to the tundra is mostly lost by evaporation, which accounts for $86 \%$, while the input to the glacier is mostly lost by melting. The relatively small heat input to the glacier and the large evaporation rate of its surroundings favour the glacier's existence. Most precipitation occurs between June and August, accounting for $66 \%$ of the annual total. Precipitation increases with altitude in average conditions during the ablation season; the annual precipitation is estimated to be about $650 \mathrm{~mm}$ at the mean equilibrium line altitude of $4030 \mathrm{~m}$. This amount is considerably larger than that of the surrounding area. Evaporation is estimated at $270 \mathrm{~mm} \mathrm{a}^{-1}$ on the tundra, reducing the runoff in a rather large proportion, and $120 \mathrm{mma}^{-1}$ on the glacier. Almost all runoff takes place between May and September, and is mostly concentrated in July and August when the glacier melt is the most intense. When air temperature is high during the ablation period, although the precipitation is less, runoff could peak because of the glacier melt. Based on the measured runoff and estimated regional precipitation and evaporation, the glacier mass balance is calculated and discussed.
\end{abstract}

\section{INTRODUGTION}

In mountainous glacierized areas, the formation of glaciers and runoff is controlled by water and heat balance. In the arid regions of China, the glacier meltwater is often an important component of the total runoff (Qu and Kang, 1990). Although the Chinese Tien Shan is situated in the arid inland area, glaciers cover the relatively large area of $9548 \mathrm{~km}^{2}$ (Liu and others, 1986) and play an important role in the formation of water resources (Qu and Kang, 1990). In order to study the distribution and interrelationship of the components of the water and heat balance in mountainous glacierized areas, combined water, heat and mass balance observations have been carried out by the Tien Shan glaciological station of the Lanzhou Institute of Glaciology and Geocryology, Academia Sinica (LIGG-AS) since 1979 (an earlier project was carried out between 1959 and 1967), and since 1985 by a cooperative research project between LIGG-AS and the Geography Institute of the Swiss Federal Institute of Technology (GI-ETH). The research basin (Fig. 1) is situated at the source region of the Ürümqi River $\left(43^{\circ} 00^{\prime}-44^{\circ} 07^{\prime} \mathrm{N}\right.$ and $\left.86^{\circ} 45^{\prime}-97^{\circ} 56^{\prime} \mathrm{E}\right)$. Its catchment area is $28.9 \mathrm{~km}^{2}$ with seven glaciers covering $5.74 \mathrm{~km}^{2}$ with respect to the total basin hydrometric station (Total Control station). The altitude of the basin ranges from 3403 to $4479 \mathrm{~m}$ a.s.l. and consists of glaciers, bare rocks, moraines and alpine tundra. There are three hydrometric stations and a standard meteorological station in the basin. Measurements of glacier mass balance are carried out regularly five to 13 times per year between April and September on Glacier No. 1; additional heat balance and precipitation measurements have been carried out on both the glacier surface and the non-glacier surface at different altitudes during selected years. The sites of the observations discussed in this paper are shown in Figure 1 and Table 1.

During 1983-84, a joint research project on glacier heat balance and climate was carried out by LIGG-AS and the Water Research Institute, Nagoya University, Japan. The results of this project show that global radiation is less on the glacier facing north than that on the Empty Cirque facing south (Bai and others, 1989), and glacier albedo is controlled strongly by surface dirtiness and snow depth (Bai and Ohata, 1989; Ohata and others, 1989).

It has been shown by the Swiss research group that, at the mean equilibrium line altitude of Glacier No. 1, for the entire melt period, the global radiation is $232 \mathrm{~W} \mathrm{~m}^{-2}$, and the shortwave and longwave net radiation are 101 and $-44 \mathrm{Wm}^{-2}$, respectively. Net radiation is $52 \mathrm{~W} \mathrm{~m}^{-2}$, with sensible heat flux of $17 \mathrm{~W} \mathrm{~m}^{-2}$, which contributes to the glacier melt. An important finding is that the latent heat of evaporation forms a large proportion, $18 \%$, of the 

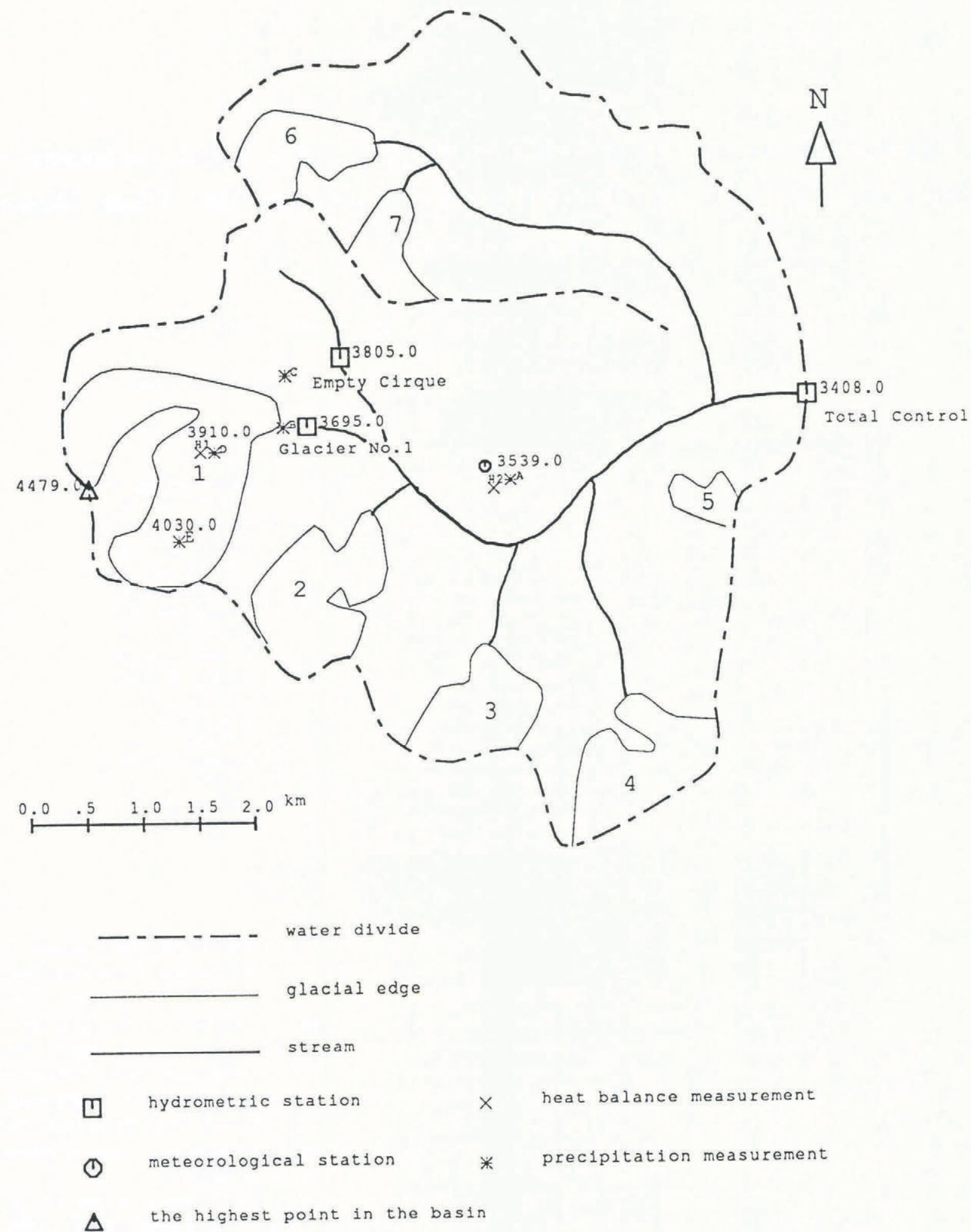

Fig. 1. The source basin of the Ürümqi River. (Numbers on glaciers represent the official numbering system of the Chinese Glacier Inventory.)

total heat source. The survival of the glaciers is to a great extent due to this large evaporation during the melt period (Ohmura and others, 1990).

Based on previous investigations and present field observations, the difference in radiation and heat balance between glacier and alpine tundra surfaces, precipitation, evaporation and runoff conditions, and the water-balance calculations, will be discussed.

\section{HEAT-BALANCE COMPARISON BETWEEN GLACIER AND ALPINE TUNDRA}

\section{Overview}

Based on simultaneous observations of heat balance on Glacier No. 1 (Calanca and Heuberger, 1990) and on alpine tundra (Zhang and others, 1990) between June 
Table 1. Water and heat-balance observations at the source area of the Ürümqi River

\begin{tabular}{|c|c|c|c|c|}
\hline Observation points & $\begin{array}{l}\text { Altitude } \\
\text { m a.s.l. }\end{array}$ & $\begin{array}{l}\text { Drainage area } \\
\mathrm{km}^{2}\end{array}$ & $\begin{array}{l}\text { Glacierized ratio } \\
\qquad\end{array}$ & Remarks \\
\hline $\begin{array}{l}\text { Glacier mass } \\
\text { balance }\end{array}$ & $3700-4225$ & - & - & $\begin{array}{l}\text { Regular observation on Glacier No. } 1 \text { by } \\
\text { LIGG-AS }\end{array}$ \\
\hline $\begin{array}{l}\text { Glacier No. } 1 \\
\text { hydrometric station }\end{array}$ & 3695 & 3.34 & 56.0 & Standard, by LIGG-AS \\
\hline $\begin{array}{l}\text { Empty Cirque } \\
\text { hydrometric station }\end{array}$ & 3805 & 1.68 & 0.0 & Standard, by LIGG-AS \\
\hline $\begin{array}{l}\text { Total Control } \\
\text { hydrometric station }\end{array}$ & 3408 & 28.9 & 19.9 & Standard, by LIGG-AS \\
\hline $\begin{array}{l}\text { Tien Shan meteor- } \\
\text { ological station }\end{array}$ & 3539 & - & - & $\begin{array}{l}\text { Standard, by Xinjiang Meteorological } \\
\text { Administration }\end{array}$ \\
\hline $\begin{array}{l}\text { Glacier heat } \\
\text { balance }(\mathrm{H} 1)\end{array}$ & 3910 & - & - & $\begin{array}{l}\text { On east branch of Glacier No. 1, by GI-ETH } \\
\text { and LIGG-AS during summer of 1985-87 }\end{array}$ \\
\hline $\begin{array}{l}\text { Tundra heat } \\
\text { balance }(\mathrm{H} 2)\end{array}$ & 3539 & - & - & By LIGG-AS during summer of 1986 \\
\hline Precipitation & $\begin{array}{l}3539(\mathrm{~A}) \\
3720(\mathrm{~B}) \\
3870(\mathrm{C}) \\
3910(\mathrm{D}) \\
4030(\mathrm{E})\end{array}$ & & & $\begin{array}{l}\text { Comparative observation for systematic } \\
\text { error correction by LIGG-AS and } \\
\text { GI-ETH during 1986-87 }\end{array}$ \\
\hline
\end{tabular}

and August 1986, the main characteristics of both surfaces are presented in Table 2.

On the glacier surface, heat input is mainly due to net radiation followed by sensible heat; heat consumption is mainly due to melt followed by evaporation. This shows that, on average, sensible heat contributes to the melt, but latent heat of evaporation reduces melt considerably (Ohmura and others, 1990). The heat balance on the alpine tundra surface is very different from that on the glacier surface. Net radiation is the only heat source to the tundra surface, amounting to more than twice that on the glacier surface, and all the other components are heat

Table 2. Heat balance on the surface of Glacier No. 1 and on the alpine tundra at the source area of the Ürümqi River 6 July-19 August 1986

\begin{tabular}{|c|c|c|c|c|c|c|c|c|c|c|}
\hline \multirow[t]{2}{*}{ Underlying surface } & \multicolumn{2}{|c|}{$\mathcal{N}$ et radiation } & \multicolumn{2}{|c|}{ Sensible heat } & \multicolumn{2}{|c|}{ Latent heat } & \multicolumn{2}{|c|}{ Melt heat } & \multicolumn{2}{|c|}{ Subsurface heat } \\
\hline & $\mathrm{W} \mathrm{m} \mathrm{m}^{-2}$ & $\%$ & $\mathrm{~W} \mathrm{~m} \mathrm{~m}^{-2}$ & $\%$ & $\mathrm{~W} \mathrm{~m} \mathrm{~m}^{-2}$ & $\%$ & $\mathrm{~W} \mathrm{~m}^{-2}$ & $\%$ & $\mathrm{~W} \mathrm{~m}^{-2}$ & $\%$ \\
\hline $\begin{array}{l}\text { Glacier No. } 1 \\
(3910 \mathrm{~m})^{*}\end{array}$ & +54.5 & 82.5 & +11.6 & 17.5 & -4.0 & 6.1 & -62.1 & 93.9 & 0 & 0 \\
\hline $\begin{array}{l}\text { Alpine tundra } \\
(3539 \mathrm{~m})\end{array}$ & +122.4 & 100.0 & -8.2 & 6.7 & -104.2 & 85.2 & -6.9 & 5.6 & -3.1 & 2.5 \\
\hline
\end{tabular}

Remarks Positive (+) symbolizes heat flux to the surface, percentage (\%) is counted separately for heat input and output. The melt heat on the alpine tundra is due to snowmelt. 
consumption. The evaporation latent heat is by far the largest heat sink, while sensible heat is small and compatible to the heat for the snowmelt, accounting for about 6 or $7 \%$ of the heat loss. The heat conducted into the ground is the least.

\section{Radiation}

\section{Seasonal variation}

During the observation period, the daily global radiation on the tundra varies synchronously with that on the glacier, but the former is larger than the latter (Fig. 2). This could be attributed to the effect of topography. The glacier faces northeast with large slope inclination, while the tundra is located in the rather open and flat part of the basin (Fig. 1). In this region, glaciers develop mainly on the north-facing slopes (Liu and Ding, 1986); the lower radiation energy on those slopes is favourable to the presence of the glaciers.

In addition to its higher mean value, the albedo on the glacier fluctuates more than that on the tundra. On the glacier surface, the precipitation is mostly in a solid form; this increases the albedo when the glacier melts. Consequently, the net radiation on the tundra is larger than that on the glacier (Fig. 2).
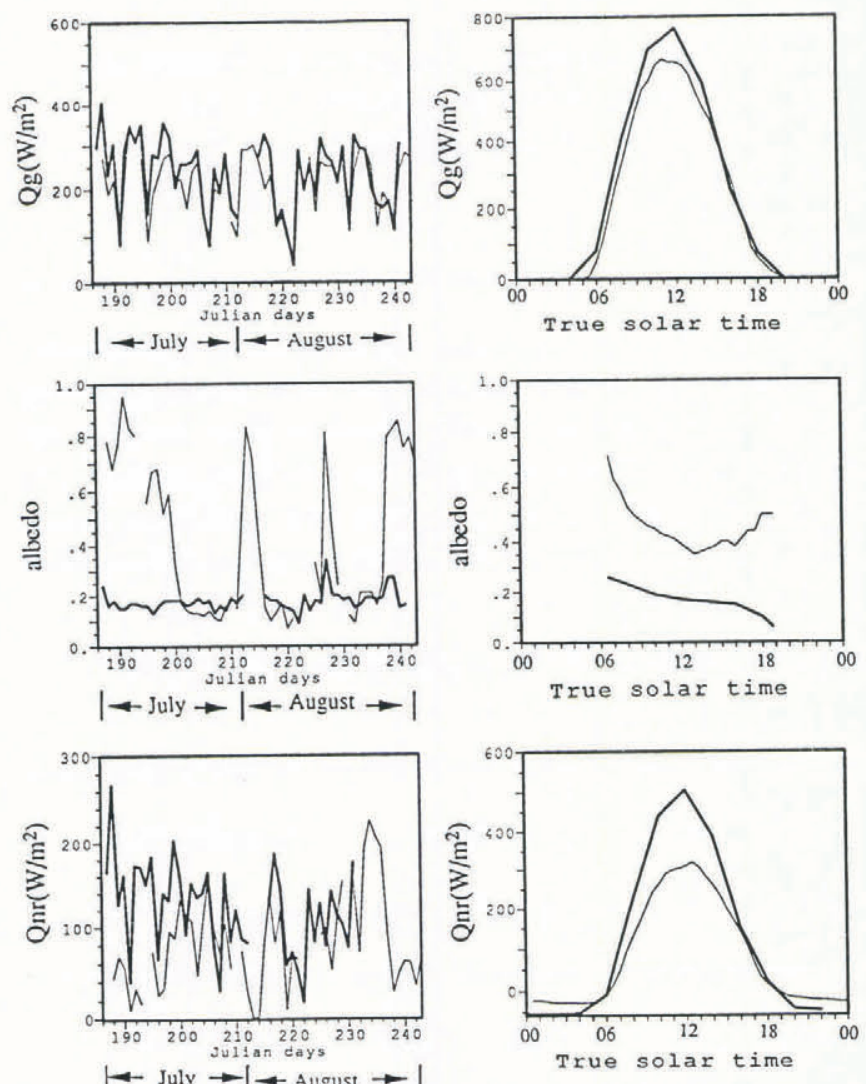

\section{Diurnal variation}

The average diurnal courses of global radiation, albedo and net radiation (Fig. 2) show that the global radiation and net radiation are larger on the tundra surface, but the albedo is much less. The melt process on the glacier during the course of a day influences the albedo considerably (Konzelmann, 1990). In the early morning, when the sun rises, the frozen glacial surface creates a high albedo which decreases with the increase of meltwater towards noon and, after that, when the melt is reduced, the albedo increases again, but is less than that in the morning because of the presence of meltwater on the surface. On the tundra surface, the diurnal course of the albedo shows a similar variation to a lesser degree, because the ground surface is frozen in the morning when daily temperature is low, and snow deposits are melted more rapidly in the afternoon.
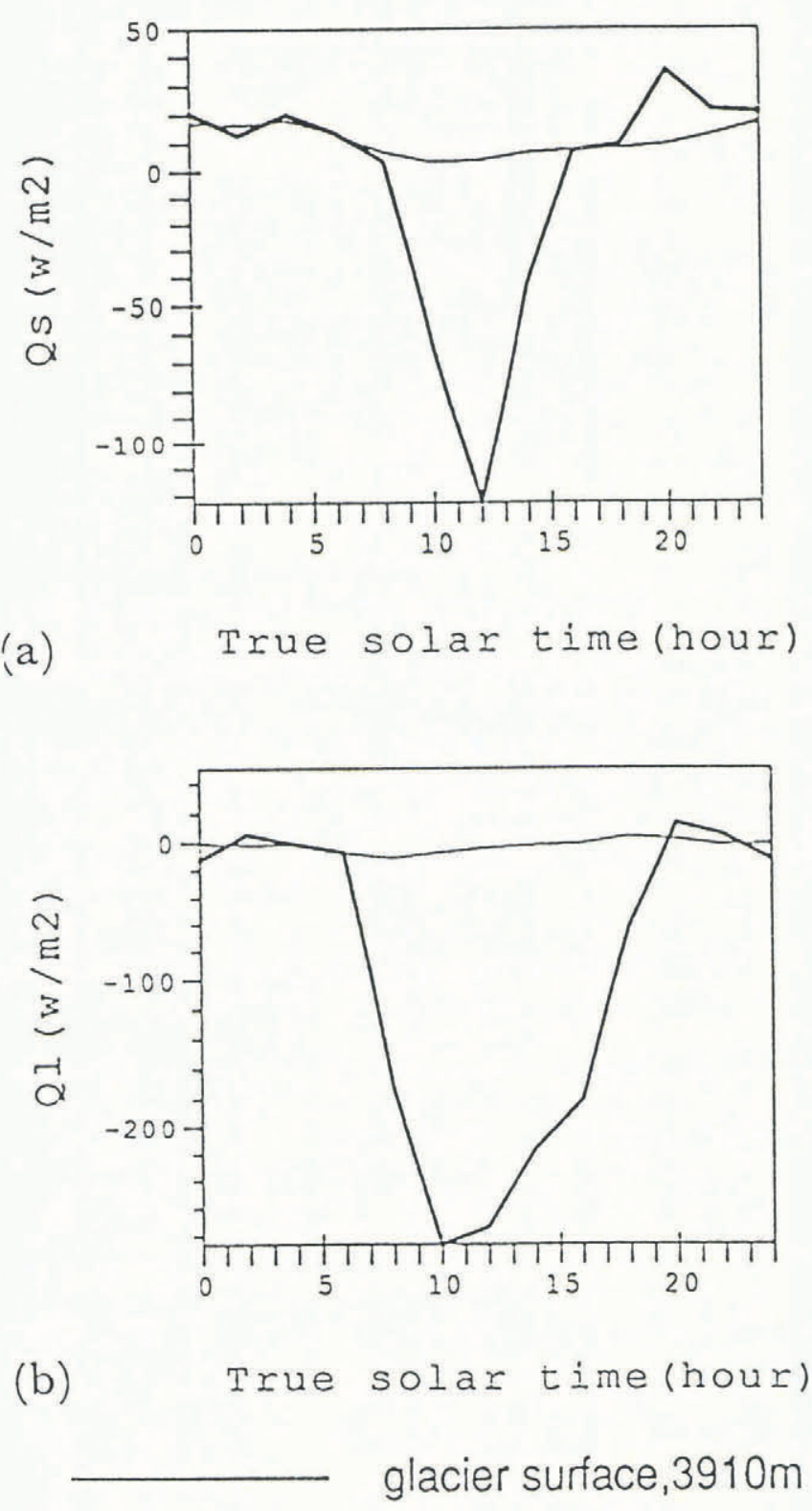

tundra surface, $3539 \mathrm{~m}$

Fig. 3. Average diurnal variations of (a) sensible heat, $Q_{\mathrm{s}}$, and (b) latent heat, $Q_{1}$, fluxes on Glacier $\mathcal{N}_{0} .1$ and the alpine tundra (July to August 1986). 


\section{Sensible and latent heat fluxes}

On the glacier surface, because of the structure of the inversion profile, the sensible heat flux is directed towards the surface during the whole day (Fig. 3). It shows a slight diurnal variation with a lower value at about the true solar noon, when the glacier melt is most rapid, which reduces the air temperature near the surface and may influence the sensible heat flux. On the tundra surface, sensible heat is directed towards the surface and the amount is relatively small during the night. After $0800 \mathrm{~h}$, it becomes negative and the absolute value increases very rapidly, reaching the maximum at $1200 \mathrm{~h}$; after that, it decreases rapidly until about $1600 \mathrm{~h}$, when it becomes positive again.

The latent heat has the same diurnal variation as that of the sensible heat (Fig. 3). On the glacier surface, it is, on average, negative, contributing to the evaporation. On the tundra surface, it is very large during the day, due to evaporation, and the maximum is at about $1000 \mathrm{~h}$ true solar time. On the glacier surface, the surface vapour pressure is limited to $6.11 \mathrm{mbar}$ during the ablation period. On the tundra, the surface vapour pressure increases with temperature, causing a large diurnal variation.

\section{Profile structure}

Figure 4 shows the average diurnal variation of the air temperature, specific humidity and wind profiles in the air layer $2 \mathrm{~m}$ above the surface during the period of glacier ablation. The air temperature on the tundra surface is always higher than that on the glacier surface. On both surfaces, the air temperature undergoes inversion at night, and maintains this inversion on the glacier during the day. Between 1000 and $1400 \mathrm{~h}$ true solar time, the air temperature profile on the tundra surface reverts to the lapse condition.

The specific humidity on the tundra surface is always higher than that on the glacier surface; it decreases with height on both surfaces, but the gradient on the tundra surface is larger. Between 2000 and $2200 \mathrm{~h}$, the specific humidity shows a slight increment with height, which could be attributed to the decrease of the air temperature near the surface at this time during the day.

The wind profiles show a regular structure on both surfaces. During the night, the wind speed on the glacier surface is more rapid than that on the tundra surface, but the latter is more rapid during the day, the change taking place at about $0800 \mathrm{~h}$ and at about $2000 \mathrm{~h}$. During the day, the warmer tundra surface shows stronger convection than the glacier surface; it could cause stronger valley breezes but, during the night, the colder glacier surface could cause stronger mountain breezes.

In the mountain glacierized basin, the underlying surface consists of a glacierized part and a non-glacierized part. Their heat conditions are different from each other. The tundra surface receives more heat than the glacier surface, but the larger evaporation rate consumes most of the heat and contributes to the low temperature of the basin. Therefore, the relatively low heat input to the glacier and the high rate of evaporation of its surroundings are favourable to the glacier.

\section{PRECIPITATION}

\section{Variation}

According to observations at the Tien Shan meteorological station ( $3539 \mathrm{~m}$ a.s.l.) in the basin between 1959 and 1989 , the mean annual precipitation is $429.3 \mathrm{~mm}$ with a standard deviation of $49.9 \mathrm{~mm}$ for the 31 years, the minimum annual precipitation is $293.8 \mathrm{~mm}$ in 1985 and the maximum $521.6 \mathrm{~mm}$ in 1971 . The mean annual air temperature is $-5.4^{\circ} \mathrm{C}$ (Table 3 ).

The precipitation is concentrated in the summer months of June, July and August, and accounts for $66 \%$ of the annual value. During these months the air temperature is high and the glacier ablation is rapid. The maximum monthly precipitation is in July, when the air temperature is also the highest of the year.

\section{Error correction for precipitation}

There are systematic observation errors in the precipitation data (Sevruk, 1986). In order to investigate them in the Tien Shan environment, a comparative field experiment was carried out using different precipitation gauges at different altitudes between 1986 and 1987 in the Ürümqi River basin (Yang and others, 1989). At the source of the river, which is heavily glacierized, the systematic errors were studied on the dynamic loss (caused by the deformation of the air flow field above the gauge orifice), wetting loss (caused by the attachment of precipitation on the inside wall of the gauge) and the evaporation loss (caused by the evaporation of the precipitation received by the gauge) for the Chinese standard rain gauges. It was found that the dynamic loss

Table 3. The annual distribution of precipitation and air temperature in the source area of the Urümqi River

Precipitation Air temperature

$\mathrm{mm} \quad{ }^{\circ} \mathrm{C}$

\begin{tabular}{llrr}
\hline & & & \\
& Jan & 2.8 & -15.7 \\
& Feb & 3.9 & -15.1 \\
& Mar & 7.4 & -10.7 \\
& Apr & 22.3 & -5.2 \\
Month & May & 48.2 & -0.6 \\
& Jun & 92.7 & 2.7 \\
& Jul & 106.2 & 4.8 \\
& Aug & 83.2 & 4.5 \\
& Sept & 47.3 & 0.3 \\
& Oct & 10.7 & -4.9 \\
& Nov & 2.8 & -10.7 \\
& Dec & 1.8 & -13.6 \\
Annual value (total for & & & \\
precipitation and mean & & & \\
for air temperature) & & 429.3 & -5.4 \\
& & & \\
\hline
\end{tabular}


Kang Ersi and others: Water and heat balance of Ürümqi River source
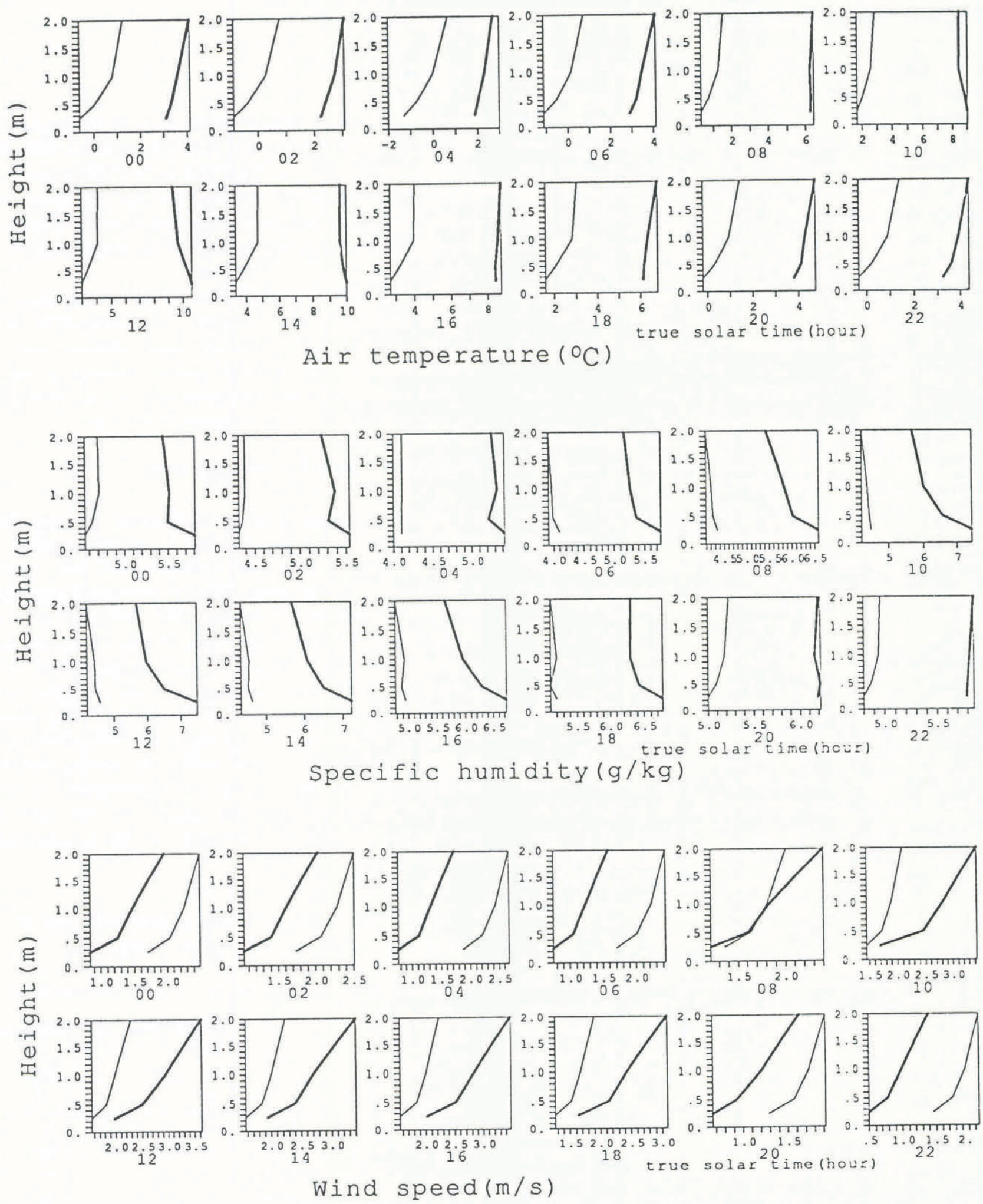

glacier surface, $3910 \mathrm{~m}$

tundra surface, $3539 \mathrm{~m}$

Fig. 4. Average diurnal variations of the profile structure on Glacier No. 1 and the alpine tundra (Fuly to August 1986). 
Table 4. The correction factor of the systematic error for the monthly observed precipitation

Month

Error source

Dynamic Wetting Evaporation

Total

\begin{tabular}{lllll} 
Jan & 1.25 & 1.43 & 1.00 & 1.68 \\
Feb & 1.26 & 1.46 & 1.00 & 1.72 \\
Mar & 1.26 & 1.35 & 1.00 & 1.61 \\
Apr & 1.27 & 1.15 & 1.00 & 1.42 \\
May & 1.16 & 1.12 & 1.06 & 1.34 \\
Jun & 1.15 & 1.08 & 1.05 & 1.28 \\
Jul & 1.14 & 1.06 & 1.04 & 1.24 \\
Aug & 1.13 & 1.06 & 1.05 & 1.24 \\
Sept & 1.15 & 1.09 & 1.05 & 1.29 \\
Oct & 1.27 & 1.20 & 1.00 & 1.47 \\
Nov & 1.25 & 1.50 & 1.00 & 1.75 \\
Dec & 1.28 & 1.46 & 1.00 & 1.74 \\
& & & & \\
\hline
\end{tabular}

caused the major part of the total observation error, accounting for $52.4 \%$; the wetting loss, $33.3 \%$; and the evaporation loss, $14.3 \%$. The correction factor for the total systematic error is 1.30 , but it changes according to season (Yang and others, 1989). Based on Table 3, the monthly correction factor is distributed to the observed precipitation in Table 4.

In the source area of the river, the precipitation is mainly in the solid form because of low air temperatures; therefore the dynamic loss consists of the main part of the error. During the winter season, precipitation is small, the air temperature is low and the evaporation loss is negligible.

\section{Altitude dependence}

The spatial distribution of precipitation in high mountain areas varies vertically and horizontally (Lang, 1989). Analysis shows that the precipitation in the Ürümqi River basin increases with altitude (Wang and Zhang, 1985; Yang, 1987; Yang and others, 1989; Blumer, 1990). In the glacierized source area of the basin, the altitude is high, but in a rather short range when compared with the whole basin. It is important to understand the distribution of precipitation in this high mountainous area, because precipitation is abundant here, glaciers are formed and play an important role in the formation of water resources. Generally, because of the lack of observational data in high mountains, the distribution of precipitation has to be estimated by means of the precipitation gradient and the observational data at a standard meteorological station in the area. Between June and August of 1987, the precipitation measurements at different altitudes of the source area were carried out by the authors in cooperation with the GI-ETH. The results show that the precipitation increases with altitude in the source area of the basin (Table 5, A) but the gradient varies with time. It is also possible to have negative gradients with altitude on occasions, but in most cases it increases with altitude (Table 5, B).

The error correction is based on snow board measurements and comparative measurements with different gauges. It is found that precipitation increases with altitude in the source area mainly in summer; other seasons do not show a clear increase with altitude. The

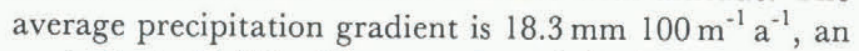
equivalent of $4.3 \%$ of the annual precipitation at the Tien Shan meteorological station in altitudinal increments of $100 \mathrm{~m}$ up to $4030 \mathrm{~m}$ at the equilibrium line according to

Table 5. Precipitation distribution with altitude at the source area of the Ürümqi River

\section{A. Result of field experiment 15 June to 31 August 1987}

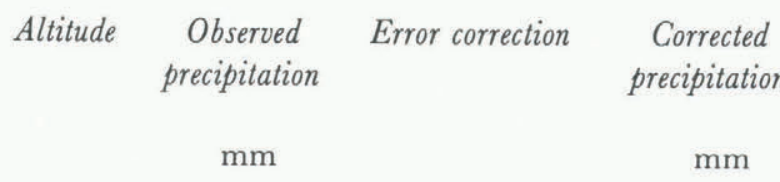

\begin{tabular}{lrrr}
\hline & & & \\
3540 & 246.9 & +56.8 & 303.7 \\
3720 & 254.6 & +62.4 & 317.0 \\
3870 & 294.1 & +56.5 & 350.6 \\
3910 & 371.2 & +100.3 & 371.5 \\
4030 & 247.0 & +146.5 & 393.5 \\
\hline
\end{tabular}

B. Observation at the meteorological station $(3539 \mathrm{~m})$ and the Glacier No. 1 hydrometric station ( $3695 \mathrm{~m}$ )

Year Altitude $\begin{gathered}\text { Precipitation } \\ \text { (May-August) }\end{gathered} \quad$ Gradient

$\mathrm{m}$

$\mathrm{mm}$ $\mathrm{mm} 100 \mathrm{~m}^{-1}$

Observed Corrected

\begin{tabular}{ccccc}
1982 & 3539 & 384.3 & 484.9 & -14.1 \\
& 3695 & 365.4 & 462.9 & \\
1983 & 3539 & 305.3 & 406.9 & 14.9 \\
& 3695 & 320.2 & 430.1 & \\
1984 & 3539 & 279.0 & 355.1 & -14.2 \\
& 3695 & 260.7 & 332.9 & \\
1985 & 3539 & 237.4 & 300.7 & 2.2 \\
& 3695 & 204.9 & 304.2 & \\
1986 & 3539 & 290.6 & 370.0 & 21.3 \\
& 3695 & 316.7 & 403.3 & \\
1987 & 3539 & 316.8 & 399.7 & 8.9 \\
& 3695 & 326.6 & 413.5 & \\
1988 & 3539 & 351.5 & 444.1 & 20.4 \\
& 3695 & 376.6 & 476.0 & \\
1989 & 3539 & 343.9 & 435.1 & 31.4 \\
& 3695 & 382.3 & 484.1 & \\
Mean & 3539 & 313.6 & 399.6 & 8.9 \\
& 3695 & 319.2 & 413.4 & \\
& & & & \\
\hline
\end{tabular}


the field experiment of 1987, when the measured precipitation was $433.5 \mathrm{~mm}$, close to the mean value of $429.3 \mathrm{~mm}$ in Table 3. Therefore, it is taken as the mean annual precipitation gradient for the first approximation. It is estimated that the mean annual precipitaiton is about $650 \mathrm{~mm}$ at $4030 \mathrm{~m}$ on the equilibrium line for the same period as shown in Table 3 . When precipitation is dealt with in individual years, the variation of precipitation gradient from year to year should be considered.

The precipitation on the glacier is abundant, compared to that in the city of Üumqi, which had an average of only $230 \mathrm{~mm}$ between 1960 and 1987 (according to the Ürümqi meteorological station, $918 \mathrm{~m}$ a.s.l.).

\section{ESTIMATION OF EVAPORATION}

\section{Evaporation from the tundra surface}

Based on field observation carried out on the tundra surface (3539 $\mathrm{m}$ a.s.1.) during summer 1986 (Zhang and others, 1990), three methods were used to estimate evaporation: profile-flux relationship, weighing lysimeter and Bowen ratio. The profile-flux relationship and the lysimeter were developed by Ohmura (1981, 1982).

The results from these three methods are similar to each other (Table 6), which means that the methods are applicable on the alpine tundra surface. The lysimeter values are taken as the reference. The total evaporation during the observation period 13 June to 31 August is $231.2 \mathrm{~mm}$.

Based on air temperature data from the standard meteorological station between 1959 and 1985, and using the Thornthwaite method, the potantial evaporation is estimated as $304 \mathrm{~mm} \mathrm{a}^{-1}$. According to the observed data, the ratio of evaporation to potential evaporation is 0.89 . Evaporation from the tundra is estimated as $270 \mathrm{~mm} \mathrm{a}^{-1}$

\section{Evaporation from the glacier surface}

Based on observations by Calanca and Heuberger (1990), the latent heat flux on the glacier between June and

Table 6. Observed evaporation on the tundra surface (mean values for time intervals, 1986)

\begin{tabular}{lccccc} 
Methods & $\begin{array}{c}16 \text { June- } \\
5 \text { fuly }\end{array}$ & $\begin{array}{c}6-31 \\
\text { fuly }\end{array}$ & $\begin{array}{c}1-3 \\
\text { August }\end{array}$ & $\begin{array}{c}4-19 \\
\text { August }\end{array}$ & $\begin{array}{r}\text { August } \\
\end{array}$ \\
& $\mathrm{mm} \mathrm{d}^{-1}$ & $\mathrm{~mm} \mathrm{~d}^{-1}$ & $\mathrm{~mm} \mathrm{~d}^{-1}$ & $\mathrm{~mm} \mathrm{~d}^{-1}$ & $\mathrm{~mm} \mathrm{~d}^{-1}$ \\
& & & & & \\
\hline & & & & & \\
$\begin{array}{l}\text { Lysimeter } \\
\text { Profile }\end{array}$ & 2.71 & 3.24 & 3.12 & 2.73 & 2.20 \\
$\begin{array}{l}\text { Bowen } \\
\text { ratio }\end{array}$ & 2.86 & 3.16 & 2.86 & 3.05 & 2.01 \\
& & 3.46 & & 2.69 & \\
\hline
\end{tabular}

August is estimated at $12.4 \mathrm{~W} \mathrm{~m}^{-2}$ and the equivalent evaporation is $39 \mathrm{~mm}$ over these three months $\left(0.4 \mathrm{~mm} \mathrm{~d}^{-1}\right.$ ) (Ohmura and others, 1990). During 1987 and 1988, Ohno investigated the evaporation at $4100 \mathrm{~m}$ on Glacier No. 1 for a few days in different seasons, obtaining values of $0.98 \mathrm{~mm} \mathrm{~d}^{-1}$ for summer, $0.21 \mathrm{~mm} \mathrm{~d}^{-1}$ for autumn, $0.13 \mathrm{~mm} \mathrm{~d}^{-1}$ for winter and $-0.25 \mathrm{~mm} \mathrm{~d}^{-1}$ for spring (personal communication from Hiroyuki Ohno). Based on the results from the GI-ETH, the annual evaporation from the glacier is approximately $120 \mathrm{~mm}$, that is $0.33 \mathrm{~mm} \mathrm{~d}^{-1}$, which is an equivalent of about $10 \mathrm{~W} \mathrm{~m}^{-2}$ latent heat flux.

The rather large evaporation rate in the glacierized basin may be attributed to the surrounding arid environment. As it consumes much more energy per unit mass than in the case of melting, glaciers will lose mass less rapidly. But on the tundra, it reduces the runoff in a large proportion.

\section{RUNOFF DISTRIBUTION}

Three hydrometric stations serve to measure discharge from the highly glacierized basin (Glacier No. 1 hydrometric station), a non-glacierized area of the basin (Empty Cirque hydrometric station) and the entire basin above $3403 \mathrm{~m}$ a.s.l. (Total Control hydrometric station). Almost all runoff takes place during the five months between May and September, and is most concentrated in the summer months of July and August when the glaciers melt rapidly (Table 7 ). During the summer, the basin which has the larger glacierized area has the largest specific discharge. Between July and August, the specific discharge from the non-glacierized part is the least, but in May and June, when the snow meltwater is the main proportion of the runoff, then the specific discharge from the non-glacierized part is larger. The high mountain regions in the Tien Shan are capable of producing much larger runoff than the surrounding regions because of larger precipitation and glacier meltwater. Meltwater from glaciers is regarded as especially important because it reaches its maximum in summer, when the surrounding regions experience the dry period and the water demand of settlements reaches its peak. This is shown clearly with a simple comparison to the precipitation in the city of Ürümqi (Table 7).

\section{WATER BALANCE}

The water balance equation is written as

$$
P-E-R=S,
$$

where $P$ is precipitation, $E$ is evaporation, $R$ is runoff and $S$ is change in storage.

In the study region, the ground is frozen for most of the year because of the low air temperature and the rather short runoff production period. The lower limit of the permafrost is at $3180-3300 \mathrm{~m}$ on sunny slopes and $2900 \mathrm{~m}$ on shadowed slopes. The active layer reaches $2 \mathrm{~m}$ at $3300 \mathrm{~m}$ in the middle of July (Qui and others, 1982). Therefore, the change in the ground water storage can be 
Table 7. The specific discharge distribution in the source area of the Ürümqi River (mean over the years)

Station

$\begin{array}{cccccc}\text { Month } & \text { Mean } & \text { Annual sum } & \text { Years } \\ \text { Mane } & \text { July } & \text { August September } & & \end{array}$

$\mathrm{mmd}^{-1} \quad \mathrm{mmd}^{-1} \quad \mathrm{mmd}^{-1} \quad \mathrm{mmd}^{-1} \quad \mathrm{mmd}^{-1} \quad \mathrm{mmd}^{-1} \quad \mathrm{~mm}$

\begin{tabular}{lcccccccc}
$\begin{array}{l}\text { Glacier } \\
\text { No. 1 }\end{array}$ & 0.23 & 2.22 & 8.23 & 7.35 & 0.78 & 3.79 & 580.1 & $\begin{array}{l}1983- \\
1989\end{array}$ \\
$\begin{array}{l}\text { Empty } \\
\text { Cirque }\end{array}$ & 1.03 & 2.88 & 4.22 & 3.06 & 0.67 & 2.38 & 364.1 & $\begin{array}{l}1983- \\
1989\end{array}$ \\
$\begin{array}{l}\text { Total } \\
\text { basin }\end{array}$ & 0.87 & 2.77 & 5.52 & 4.15 & 0.73 & 2.82 & 431.7 & $\begin{array}{l}1983- \\
1989\end{array}$ \\
$\begin{array}{l}\text { Precipitation of } \\
\text { city of Ürümqi* }\end{array}$ & 0.81 & 0.97 & 0.52 & 0.61 & 0.47 & 0.76 & 195 & $1961-$ \\
\hline
\end{tabular}

*For comparison, at the Ürümqi meteorological station, $918 \mathrm{~m}$ a.s.l.

neglected. Other storage areas, such as the active layer, show only minor changes. The glacier mass balance is taken as the main storage change of the water balance equation. For the glacierized basin, the water balance equation is written in the following form:

$$
\begin{gathered}
B F_{\mathrm{g}}=P_{\mathrm{g}} F_{\mathrm{g}}-E_{\mathrm{g}} F_{\mathrm{g}}+C_{\mathrm{r}} P_{\mathrm{ng}} F_{\mathrm{ng}}-R_{\mathrm{d}}\left(F_{\mathrm{g}}+F_{\mathrm{ng}}\right) \\
B=P_{\mathrm{g}}-E_{\mathrm{g}}+C_{\mathrm{r}} P_{\mathrm{ng}} \frac{F_{\mathrm{ng}}}{F_{\mathrm{g}}}-R_{\mathrm{d}}\left(1+\frac{F_{\mathrm{ng}}}{F_{\mathrm{g}}}\right)
\end{gathered}
$$

where $B$ is the glacier mass balance, $\mathrm{P}_{\mathrm{g}}$ is precipitation on the glacier $(\mathrm{mm}), E_{\mathrm{g}}$ is evaporation on the glacier $(\mathrm{mm})$, $F_{\mathrm{g}}$ is glacier area $\left(\mathrm{km}^{2}\right), P_{\mathrm{ng}}$ is precipitation on the nonglacierized area $(\mathrm{mm}), C_{\mathrm{r}}$ is runoff coefficient on the nonglacierized area, $F_{\mathrm{ng}}$ is non-glacierized area $\left(\mathrm{km}^{2}\right)$, and $R_{\mathrm{d}}$ is runoff $(\mathrm{mm})$.

The precipitation measurements made at the meteorological station are corrected by systematic error correction factors. Then the precpitation at the mean equilibrium line $(4030 \mathrm{~m})$, which is very close to the mean altitude of the glacier $(4024 \mathrm{~m})$, is calculated according to the altitude gradient of precipitation. The precipitation at the equilibrium line is taken to be the mean precipitation in the glacierized basin. The mean gradient of $18.3 \mathrm{~mm}$ $100 \mathrm{~m} \mathrm{a}^{-1}$ is used for the calculation in Table $8, \mathrm{~A}$, then the gradient in Table 5, B, is used for the calculation in Table $8, \mathrm{~B}$. The annual glacier evaporation is assumed to be $120 \mathrm{~mm}$. The runoff from the non-glacierized part is determined by the runoff coefficient of the Empty Cirque, which is considered to be representative for the nonglacierized area. Based on the measured runoff and precipitation at the Empty Cirque, the runoff coefficient is calculated: the mean value is 0.66 for $1982-89$. The mass balance for Glacier No. 1 is then calculated by means of Equation (3).

The water-balance calculation is given in Table 8; the symbols are explained in Table 9.

Since glacier runoff takes place mostly in July and August, the mean air temperature of July and August at the meteorological station is taken as an index for heat conditions to the basin. The main points in Table 8 are as follows:

(1) When air temperature is high during the period of ablation, runoff could also be high, despite low precipitation such as that observed in 1985 and 1986.

(2) When precipitation is high and air temperature is also high, runoff and negative mass balance are both high. This occurred in 1988, as an example.

(3) When precipitation and mass balance are both small, runoff is lowest, as in 1984, for example.

(4) When glacier mass balance is positive, precipitation may cause an increase in runoff, as occurred in 1983 and 1989.

(5) Mass balance calculated from the precipitation gradient of individual years has smaller absolute error than that calculated from the mean gradient. The yearto-year change in the gradient must be considered when calculating the water balance.

There have been previous studies on water balance in the Ürümqi River basin. Yang (1987) calculated the water balance in the mountainous area of the basin based on precipitation and runoff measurements. Zhang and Chen (in press) compared calculations of water balance of the basin using two groups of equations, one with measured precipitation and another with error-corrected precipitation, and concluded that the latter results were closer to the real conditions. The present study concentrates on a highly glacierized basin, which is dealt with as a glacierized part and a non-glacierized 
Kang Ersi and others: Water and heat balance of Ürümqi River source

Table 8. Water balance calculation of the Glacier No. 1 basin

A. Application of precipitation gradient in Table 5, A.

Measured

Year

$\begin{array}{cccccccc}P_{\mathrm{m}} & T_{\mathrm{m}}(7-8) & R_{\mathrm{d}} & B_{0} & P_{\mathrm{mc}} & \begin{array}{c}\text { Mean } \\ P_{\mathrm{gra}}\end{array} & \text { Non-glacierized } \\ & & & & & P_{\mathrm{ng}} C_{\mathrm{r}}\end{array}$

$\mathrm{mm} \quad{ }^{\circ} \mathrm{C} \quad \mathrm{mm} \quad \mathrm{mm}$

$$
\mathrm{mm} \underset{100 \mathrm{~m}^{-1} \mathrm{a}^{-1}}{\mathrm{~mm}}
$$

Estimated

Glacierized area

$P_{\mathrm{g}} \quad E_{\mathrm{g}} \quad B_{\mathrm{c}} \quad\left|B_{0}-B_{\mathrm{c}}\right|$

$\mathrm{mm} \quad \mathrm{mm} \quad \mathrm{mm} \quad \mathrm{mm}$

$\begin{array}{rrrrrrrrrrrrrr}1982 & 488.2 & 4.0 & 430 & -45 & 634.7 & 18.3 & 724.7 & 0.66 & 724.7 & 120 & +213 & 258 \\ 1983 & 400.7 & 4.9 & 420 & +100 & 520.9 & 18.3 & 610.9 & 0.66 & 610.9 & 120 & +58 & 42 \\ 1984 & 395.5 & 4.7 & 362 & -8.3 & 514.2 & 18.3 & 604.2 & 0.66 & 604.2 & 120 & +151 & 234 \\ 1985 & 290.0 & 4.8 & 646 & -612 & 377.0 & 18.3 & 467.0 & 0.66 & 467.0 & 120 & -568 & 47 \\ 1986 & 372.9 & 5.8 & 954 & -669 & 484.8 & 18.3 & 574.8 & 0.66 & 574.8 & 120 & -951 & 282 \\ 1987 & 436.1 & 5.4 & 411 & -176 & 566.9 & 18.3 & 656.9 & 0.66 & 656.9 & 120 & +144 & 320 \\ 1988 & 498.9 & 5.0 & 757 & -642 & 648.6 & 18.3 & 738.6 & 0.66 & 738.6 & 120 & -350 & 292 \\ 1989 & 479.5 & 4.5 & 526+106 & 623.4 & 18.3 & 713.4 & 0.66 & 713.4 & 120 & +24 & 82 \\ & & & & & & & & & & & & & \\ \text { Mean } & 420.2 & 4.9 & 563 & -256 & 546.3 & 18.3 & 636.2 & 0.66 & 636.2 & 120 & -159 & 97 \\ \end{array}$

B. Application of precipitation gradient in Table 5, B.

\section{Measured}

Year

$$
P_{\mathrm{m}} \quad T_{\mathrm{m}}(7-8) \quad R_{\mathrm{d}} \quad B_{0}
$$

$\mathrm{mm} \quad{ }^{\circ} \mathrm{C} \quad \mathrm{mm} \quad \mathrm{mm}$

$$
\begin{array}{cc}
P_{\mathrm{mc}} \quad \text { Mean } \\
& P_{\text {gra }}
\end{array}
$$

$\mathrm{mm}$
Estimated

Non-glacierized

$P_{\mathrm{ng}} \stackrel{\text { area }}{\quad C_{\mathrm{r}}}$

$\mathrm{mm}$ 
and Professor H. Lang for their support to the work both in the field and in the laboratory. Their comments and suggestions were very valuable to the improvement of this paper. Many thanks also to the staff of the Tien Shan

Symbols

\section{Meaning}

$\begin{array}{ll}P_{\mathrm{m}} & \text { Precipitation at the Tien Shan meteoro- } \\ (\mathrm{mm}) & \text { logical station, total of hydrological year, } \\ & \text { October-September }\end{array}$

$T_{\mathrm{m}}(7-8) \quad$ Mean air temperature between July (7) and $\left({ }^{\circ} \mathrm{C}\right) \quad$ August (8) at the Tien Shan meteorological station

\begin{tabular}{|c|c|}
\hline $\begin{array}{l}B_{0} \\
(\mathrm{~mm})\end{array}$ & Measured glacier mass balance \\
\hline $\begin{array}{l}B_{\mathrm{c}} \\
(\mathrm{mm})\end{array}$ & Calculated glacier mass baalnce \\
\hline $\begin{array}{l}P_{\mathrm{mc}} \\
(\mathrm{mm})\end{array}$ & Error corrected precipitation $P_{\mathrm{m}}$. \\
\hline $\begin{array}{l}P_{\text {gra }} \\
\left(\mathrm{mm}^{-1} 100 \mathrm{~m}^{-1}\right. \\
\left.\mathrm{a}^{-1}\right)\end{array}$ & Precipitation altitude gradient \\
\hline $\begin{array}{l}F_{\mathrm{g}} \\
\left(\mathrm{km}^{2}\right)\end{array}$ & $\begin{array}{l}\text { Glacier area, } F_{\mathrm{g}}=1.87 \text { for Glacier No. } 1 \\
\text { basin }\end{array}$ \\
\hline $\begin{array}{l}F_{\mathrm{ng}} \\
\left(\mathrm{km}^{2}\right)\end{array}$ & $\begin{array}{l}\text { Non-glacierized area, } F_{\mathrm{g}}=1.47 \text { for Glacier } \\
\text { No. } 1 \text { basin }\end{array}$ \\
\hline $\begin{array}{l}E_{\mathrm{g}} \\
(\mathrm{mm})\end{array}$ & Glacier evaporation, $E_{\mathrm{g}}=120 \mathrm{~mm} \mathrm{a}^{-1}$ \\
\hline$C_{\mathrm{r}}$ & $\begin{array}{l}\text { Runoff coefficient for non-glacierized area, } \\
C_{\mathrm{r}}=0.66\end{array}$ \\
\hline
\end{tabular}

surroundings are favourable conditions for the existence of the glacier. All the runoff of the glacierized basin takes place between May and September, particularly in July and August when the glaciers melt rapidly. The basin with the larger glacierized proportion has the most specific discharge. When air temperature is high during ablation, although precipitation is less, runoff could increase because of the large negative glacier mass balance. Therefore, the glacierized basins are important for the formation and regulation of water resources in the arid area inland. The accuracy of water-balance calculation of the high mountain glacierized basin depends on the estimation of area evaporation and precipitation. Mass balance calculated by the waterbalance method has less relative error to the observed values when the precipitation gradient is chosen for individual years.

\section{ACKNOWLEDGEMENTS}

The authors are very grateful to Professor A. Ohmura glaciological station for their help during the field work.

\section{REFERENCES}

Bai Zhongyuan, T. Ohata and K. Higuchi. 1989. Calculation results of radiational climate in glacierized cirque and glacier-free cirque at the headwater of Ürümqi River in Tien Shan mountains. F. Glaciol. Geocryol., 11(4), 336-349. [In Chinese with English abstract.]

Blumer, F. 1990. Precipitation conditions in Xinjiang Province. Zürcher Geogr. Schr. 38, 74-103.

Calanca, P. and R. Heuberger. 1990. Energy balance. Zürcher Geogr. Schr. 38, 60-70.

Konzelmann, T. 1990. Radiation. Zürcher Geogr. Schr. 38, 43-58.

Lang, H. 1989. Sloping land with snow and ice. In Falkenmark, M. and T. Chapman, eds. Comparative hydrology. Mayenne, Unesco, 146-162.

Liu, C. and L. Ding. 1986. Distribution and active features of the glaciers in interior drainage area of Junggar basin in northwest Tien Shan mountains. In Lanzhou Institute of Glaciology and Geocryology. Academia Sinica, ed. Glacier inventory of China III. Tien Shan mountains (interior drainage area of Junggar basin in northwest). Beijing, Science Press, 12-13.

Liu, C., Z. Lai and Z. Cao. 1986. Some comments on the glacier inventory of interior drainage area of Junggar basin in northwest Tien Shan mountains. In Lanzhou Institute of Glaciology and Geocryology. Academia Sinica, ed. Glacier inventory of China III. Tien Shan mountains (interior drainage area of Junggar basin in northwest). Beijing, Science Press, 1.

Ohata, T., Bai Zhongyuan and Ding Liangfu. 1989. Heat balance study on Glacier No. 1 at head of Ürümqi River, Tien Shan mountains, China. 7. Glaciol. Geocryol., 11 (4), 298-309.

Ohmura, A. 1981. Climate and energy balance on Arctic tundra. Zürcher Geogr. Schr., 3(123-124), 266-289.

Ohmura, A. 1982. Climate and energy balance on the Arctic tundra. 7. Climatol., 1982(2), 67-69.

Ohmura, A., H. Lang, F. Blumer and D. Grebner. 1990. Glacial climate research in the Tien Shan. Zürcher Geogr. Schr., 38(4), 37-42

Qiu, G., S. Li and L. Ting. 1982. Some new data in high mountain permafrost and periglacial phenomena in the vicinity of Tien Shan Station. Annual Report on the Work at Tien Shan Glaciological Station, 1, 113-114.

Qu, Y. and E. Kang. 1990. A summary of researches on glacial water resources in China. In Chinese Society of Geography, ed. Proceedings of the Second Symposium on Glaciology and Geocryology. Lanzhou, Gansu People's Press, 16-17.

Sevruk, B., ed. 1986. Correction of precipitation measurements. Zürcher Geogr. Schr. 23.

Wang Dehui and Zhang Peiyuan. 1985. On the valley climate of Ürümqi River in the Tien Shan mountains. 7. Glaciol. Geocryol., 7(3), 239-248. [In Chinese with English abstract.] 
Yang Daqing, Shi Yafeng, Kang Eris and Zhang Yinsheng. 1989. Research on analysis and correction of systematic errors in precipitation measurement in Wulumqi River basin, Tien Shan. In Sevruk, B., ed. Precipitation measurement. WMO/IAHS/ETH workshop on precipitation measurement, St Moritz, 3-7 December 1989. Zürich, Swiss Federal Institute of Technology, 173179.

Yang, Z. 1987. A preliminary analysis of water balance in the mountainous area of the Ürümqi River. In Chinese Society of Geography, ed. Proceedings of the Second Symposium on Glaciology and Geocryology. Lanzhou, Gansu People's Press, 248-258.

Zhang, G. and X. Chen. In press. Water balance of the mountainous area in the Ürümqi River basin. In Shi, Y., and others, eds. Formation and estimation of mountain water resources in the Ürümqi River basin. Beijing, Science Press.

Zhang, Y., E. Kang and D. Yang. 1990. The study of evapotranspiration in the headwaters of Ürümqi River. In Lanzhou Institute of Glaciology and Geocryology. Academia Sinica, ed. Proceedings of the Fourth National Conference on Glaciology and Geocryology (Glaciology). Beijing, Science Press, 87-94.

The accuracy of references in the text and in this list is the responsibility of the author/s, to whom queries should be addressed. 